\title{
Social Cooperatives:
}

\section{When Social Enterprises meet the Cooperative Tradition}

\author{
Jacques Defourny $^{1}$ and Marthe Nyssens ${ }^{2}$ \\ Paper to be presented at the Euricse - ICA International Conference \\ "Promoting the Understanding of Cooperatives for a Better World" \\ Venice, March 15-16, 2012.
}

\section{Introduction}

On the basis of the co-operative principles as adopted by the Equitable Pioneers of Rochdale and later by the International Cooperative Alliance (ICA), it is possible to argue that a great deal of cooperatives have always had a stronger orientation toward the general interest or the public good than most traditional private companies. Indeed, among the co-operative principles reformulated by the ACI in 1995 at its $100^{\text {th }}$ anniversary, the $7^{\text {th }}$ and last one explicitly refers to the co-operatives' commitment to contribute to a sustainable development of the whole community. More generally concerns for fairer economic relations and for promotion of economic democracy at large have always been parts of a true co-operative spirit.

From a more pragmatic point of view, it can also be observed that many large cooperatives first focused on the interests of their members and later opened members' advantages to all their customers or users with or without a symbolic purchase of member share. Moreover, it is not unusual to see co-operatives socializing a part of their profits through support provided to community-oriented projects although this may also be seen as a more common CSR policy. In any case, the border between co-operative members' interests and a larger community interest is sometimes blurred.

However, in spite of some explicit or implicit social contents in many co-operative behaviours, there is no doubt that a new type of co-operative appeared when launched by members seeking first to provide answers to needs of a whole community or some target groups in the community and not primarily to their own common needs. Although such cooperatives with a primary social aim may or even must involve in their membership various stakeholders including persons from the group of beneficiaries, there is actually a difference between such social cooperatives and most if not all traditional categories of co-operatives. Moreover, social co-operatives are emerging in many fields of activity which were not covered by traditional forms of co-operatives, such as work integration of disadvantaged persons, delivery of social services to vulnerable groups, rehabilitation of deprived areas, and so on.

\footnotetext{
${ }^{1}$ EMES and University of Liege, HEC-ULg Department of Economics and Centre for Social Economy.

${ }^{2}$ EMES and Catholic University of Louvain, Department of Economics and CERISIS, CIRTES.
} 
The concept of social co-operative made its first official appearance in the early 1990s, more precisely in 1991 when the Italian parliament adopted a law creating a specific legal form for "social co-operatives" which underwent a quite remarkable development. Since then, social co-operatives have also become a new type of co-operative in various countries which also set up specific legal frameworks for such enterprises: Portugal (1996 and 1998), Spain (1999), France (2001), Poland (2006) and Greece (1999 and 2011) as well as some other countries like South Korea (2011) created legal frameworks devoted to co-operatives with an explicit primary aim to serve the community or a specific group in the community different from the co-operative's membership.

In various other countries, more open legal framework have been adopted to support the development of "social enterprises" which have been increasingly promoted by public authorities or private bodies such as philanthropic foundations. The concept of social enterprise, which includes social cooperatives as one model among others, helps to identify entrepreneurial dynamics driven by a social aim. In those contexts, co-operatives with a primary social aim often emerged and experienced a significant development by adopting a "social enterprise" label and/or by fulfilling conditions allowing them to benefit from various types of support designed for social enterprises at large. Belgium (1995), Finland (2003), Lithuania (2004), the United Kingdom (2005), Italy (2005), South Korea (2007) have passed laws creating new legal frameworks for social enterprises while generally allowing most traditional legal forms of enterprise, including co-operatives, to be used provided they are combined with specific features characterizing a primary social purpose orientation (Galera and Borzaga, 2009)

More generally, the emergence of social co-operatives and social enterprises more or less explicitly related to the cooperative tradition cannot be understood without a more detailed analysis of the worldwide fast growing interest towards social enterprise and social entrepreneurship since the mid-1990. What is striking however is that the cooperative component or version of this overall social enterprise upsurge has mainly taken place in Europe and partly in Eastern Asia (Defourny and Kim, 2011) while the cooperative tradition and movements do not seem to have taken an important place so far in the United States where a strong interest towards social enterprise could be observed from the same period.

Against such a background, the first objective of the present paper is to show why and how European contexts historically paved the way for social enterprise developments which gave birth to social co-operatives or cooperative-like social enterprises in many countries and to analyse briefly to what extent such backgrounds were clearly different in the United States (section 1). As a significant part of social enterprise literature originates in the US and today exert a clear influence at the world level, we will also look at the main conceptualizations of social enterprise as they have been shaped in both regions and to what extent they give place to social co-operatives (section 2), Then, we will show how a major European conception of social enterprise actually fits the co-operative tradition and even more precisely the "world standards of social co-operatives" as they have been recently formulated by CICOPA, a sectoral organization of the International Co-operative Alliance (section 3). Finally, we will try to place social co-operatives in a longer historical perspective to show that new waves and/or new types of co-operatives generally emerge in times of deep transformations of the whole economic system when 
some basic conditions are met. We will thereby suggest social co-operatives may expect promising developments provided key factors actually play their expected roles (section 4).

\section{The socio-economic context of social enterprise emergence}

\subsection{The European context}

In most Western European countries, third sector organizations - such as non-profit organizations, co-operatives and mutual societies - were already playing a significant role in the provision of services well before the Second World War. Their importance became greater in the $1950 \mathrm{~s}$, with some emblematic initiatives set up to combat housing and poverty problems. Many of these organizations were inspired by a (Christian) charitable tradition, but another stream of inspiration stressed participation and mutual aid principles. In the late 1960s and 1970s, the quest for more democracy and equality in all spheres of life led to a blooming of civil society movements addressing major societal issues, both through advocacy and provision of services.

In the late 1970s-early 1980s, the persistence of structural unemployment in many European countries, the need to reduce state budget deficits, the need for more active integration policies raised the question of how far the third sector could help to meet these challenges. Indeed, social actors, such as social workers and associative militants, were facing a lack of adequate public policy schemes to tackle the increasing exclusion of some groups (such as long-term unemployed people, low-qualified people, people with social problems, etc.) from the labour market or more generally from society. In such an overall context, the answers given to these emerging challenges by each country varied according to the specificities of the different European models. ${ }^{3}$

\section{The Bismarckian countries}

In the countries with a Bismarckian tradition - which, according to the Esping-Andersen typology, can also be referred to as the countries belonging to the "corporatist" group (namely Belgium, France, Germany, and Ireland ${ }^{4}$ ), non-profit private organizations, mainly financed and regulated by public bodies play an important role in the provision of social services (Salamon et. al 2004).

During the 1980s, public bodies, faced with high rates of unemployment and a crisis in public finances, stopped relying exclusively on passive labour market policies based on a system of allocation of cash benefits to the unemployed and developed active labour policies, which aimed to integrate the unemployed into the labour market through professional training programs, job subsidy programs, etc.

In a context of lasting collaboration between the state and non-profit organizations in the provision of social services, public bodies heavily relied on associations for the implementation of this "second labour market program". This kind of public scheme

\footnotetext{
${ }^{3}$ Defourny et al. (1998); Spear et al. (2001); Nyssens (2006).

${ }^{4}$ The inclusion of Ireland in this first group may seem rather odd. However, Ireland has one of the highest shares of employment in the non-profit sector, and the latter relies heavily on public funding. Actually, some research has shown that Ireland is a borderline case between the "liberal" and the "corporatist" state (Hicks and Kenworthy 2003).
} 
fostered the trend toward a more productive role of and entrepreneurial dynamics within the non-profit sector.

\section{The Nordic countries}

The Nordic countries are characterised by the highest level of welfare expenditures in Europe and correspond to the "social democratic" group of Esping-Andersen's typology. In these countries, there is traditionally a division of tasks between the state, the business community, and civil society (Stryjan, 2006). The welfare state is expected to deliver welfare, the business sector ensures the production, the accumulation, and the creation of jobs, and civil society focuses on the articulation of interests and the shaping of the broad societal agenda. These countries also have a tradition of a co-operative movement, with, inter alia, workers or farmers cooperatives (Hulgård, 2004).

In the 1980 s, in a context characterized by the emergence of new challenges, new dynamics emerged in this cooperative sector. In Sweden, the first new worker cooperatives were initiated in the wake of the psychiatric care reform of 1989 (that phased out large closed-environment mental health institutions) by actors within the field of mental care: care personnel, patients and ex-patients (Stryjan, 2004). As the expansion of the Swedish public childcare sector slowed down during the 1980s, parent cooperatives experienced a rapid growth, in the framework of a search for new pedagogical models (Pestoff, 2004). With the emergence of these new forms of cooperatives, a new actor, which had traditionally been identified as part of the business sector, appeared in the landscape of the production of welfare.

\section{The United Kingdom}

The UK is traditionally viewed as emblematic of the liberal model. In this configuration, a lower level of government social spending is associated with a relatively large voluntary sector relying mostly on private resources (Salamon et al., 2004). The situation in the UK, though, could rather be described as "mixed": indeed, the experience of the two World Wars led national public authorities to develop various social programs with universal coverage, in the framework of which charities were supported through public subsidies (Lewis, 1999).

This landscape was challenged in the 1970s and 1980s by a new public management approach that stressed quasi-market mechanisms to increase efficiency in service provision. Within a quasi-market, the state still contributes to the financing and the regulation of the service but provision is open to all kinds of organisations: public sector, third sector and for-profit sector providers compete on the market. The UK community care reform of the early 1990s was emblematic of this trend.

In this context, it seems what was challenged was not so much the level of social expenditures but rather the instruments through which the government supported third sector organizations: public money took the form of contracts and third-party payments instead of grants.

\section{The Southern countries}


In Southern countries, like Spain, Italy or Portugal, welfare spending in general is lower and the provision of social services financed by the state, in particular, is underdeveloped. Families are considered as the key actor in welfare provision. Historically, Churchrelated charitable organizations have also played a central role as providers of social services, but this responsibility has been controlled or limited by the state in the $20^{\text {th }}$ century, especially during the fascist period, in order to control civil society. This explains why, in Italy, for example, in the 1970s, non-profit organisations were relatively few, and they were merely confined to advocacy activities (Borzaga, 2004). Countries as Spain and Italy are also characterized by a strong co-operative tradition.

In this context, it is not surprising that in the late 1980s, new co-operative initiatives emerged in Italy to respond to unmet needs, especially in the field of work integration as some groups were increasingly excluded from the labour market - as well as in the field of personal services - in a context of rapid aging of the population and changes in family structures. In contrast to traditional co-operatives, that were primarily oriented toward members' interests, these initiatives were serving a broader community and putting greater emphasis on the dimension of general interest. They also differed from traditional co-operatives in that they often combined different types of stakeholders in their membership (paid workers, volunteers and other supporting members, etc.), whereas traditional co-operatives are usually single-stakeholder organizations.

Although it may have been used elsewhere previously, the concept of "social enterprise" as such seems to have first appeared in this country, where it was promoted through a journal launched in 1990 and entitled Impresa sociale. The concept was introduced at that time to designate these pioneering initiatives for which the Italian Parliament created the legal form of "social co-operative" one year later.

As already mentioned, after the pioneering Italian law adopted in 1991, several other European countries introduced new legal forms reflecting the entrepreneurial approach adopted by this increasing number of "not-for-profit" organizations focusing on a social mission, even though the terms of "social enterprise" or "social co-operative" were not always used as such in the legislation (Defourny and Nyssens, 2008). In some cases, these new legal forms were of the co-operative type while others represented more open models of social enterprise only partly inspired by the cooperative tradition.

\subsection{A brief comparison with the North-American context}

In the US, the first root regarding the debate on social entrepreneurship and social enterprises refers to the use of commercial activities by non-profit organizations in support of their mission. As summarized by Kerlin (2006), although such behaviour can be traced back to the very foundation of the US, when community or religious groups were selling homemade goods or holding bazaars to supplement voluntary donations, it gained a particular importance in the specific context of the late 1970s and 1980s. Indeed, when the federal government launched the Great Society programs in the 1960s, a significant share of the huge funds invested in education, health care, community development and poverty programs was channelled through nonprofits operating in these areas, instead of being managed by an enlarged public bureaucracy. Such a strategy of course strongly supported the expansion of existing nonprofits as well as the creation of many new ones. However, the downturn in the economy in the late 1970s and the 
increased competition for philanthropic funding led nonprofits to face more difficulties in their financing strategy. Nonprofits then began to expand their commercial activities to fill the gap in their budget through the sale of goods or services not directly related to their mission.

Based on a broader vision of entrepreneurship, the second root of this debate can be traced back to B. Drayton and Ashoka, the organization he founded in 1980, as its primary driving forces. The mission of Ashoka was (and still is) "to find and support outstanding individuals with pattern setting ideas for social change". ${ }^{5}$ Ashoka focuses on the profiles of very specific individuals, first referred to as public entrepreneurs, able to bring about social innovation in various fields, rather than on the forms of organisation they might set up. Various foundations involved in "venture philanthropy", such as the Schwab Foundation and the Skoll Foundation, among many others, have embraced the idea that social innovation is central to social entrepreneurship and have supported social entrepreneurs.

Even if the Canadian debate on social enterprise shares many features with its US neighbour, it is more embedded in a collective approach to socio-economic innovation (Mendell, 2010). Canadian social enterprises are rooted in a long history of cooperatives and community initiatives. Community economic development corporations are an emblematic example of this trend. They have been established in the early 1980's in urban neighborhoods in Québec to tackle social exclusion of emerging groups in a context of economic crisis. They developed new socio-economic approaches to local development through a process of "institutionalized collaboration between the private sector, community organizations, the labour and social movements" (Mendell, 2010, Favreau, 1998). Inspired by the Italian social cooperative model, legislation was passed in 1997 establishing solidarity cooperatives that include citizens as members.

Among common features on both sides of the Atlantic, we note that the field developments around new entrepreneurial behaviours driven by a primary social purpose mainly took place within the third sector. However, the latter includes cooperatives in Europe and Canada. Indeed, according to most European traditions (Evers and Laville 2004), the third sector brings together co-operatives, associations, mutual societies and increasingly foundations, in other words, all not-for-profit organizations, i.e. organizations not seeking profit maximization for those who control them. The third sector they form together is labeled the "social economy" in some European countries (as well as in Canada) 6 , a way to insist on the quest for democracy through economic activity, which has been at the heart of many pioneering initiatives of the $19^{\text {th }}$ and $20^{\text {th }}$ century across Europe. This has profound implications, as we shall see, for subsequent conceptual evolutions of social enterprise and entrepreneurship.

\footnotetext{
${ }^{5}$ Drayton and MacDonald (1993:1).

${ }^{6}$ For a discussion of this concept, see Defourny (2001).
} 


\section{Major conceptualizations of social enterprise and social entrepreneurship}

Let us first examine how conceptualizations of social enterprise and social entrepreneurship were shaped in the United States. Then we will be best placed to highlight the specificities of European approaches to the same notions.

When looking at the US landscape, what is striking is the diversity of concepts which have been used since the early 1980s to describe entrepreneurial behaviours with social aims that developed in the country, mainly although not exclusively within the non-profit sector: "non-profit venture", "non-profit entrepreneurship", "social-purpose endeavour", "social innovation", "social-purpose business", "community wealth enterprise", "public entrepreneurship", "social enterprise"... Although the community of non-profit studies did use several of such terms, the conceptual debate has been mainly shaped by scholars belonging to business schools. To classify the different conceptions, Dees and Anderson (2006) have proposed to distinguish two major schools of thought. The first school of thought on social enterprise refers to the use of commercial activities by non-profit organizations in support of their mission. Organizations like Ashoka fed a second major school, named the "social innovation" school of thought.

\section{The "earned income" school of thought}

The first school of thought set the grounds for conceptions of social enterprise mainly defined by earned-income strategies. The bulk of its publications was mainly based on nonprofits' interest to become more commercial (Young and Salamon, 2002) and could be described as "prescriptive": many of them came from consultancy firms and they focused on strategies for starting a business that would earn income in support to the social mission of a non-profit organization and that could help diversify its funding base (Skloot, 1987). In the late 90s, the Social Enterprise Alliance, a central player in the field, defined social enterprise as "any earned-income business or strategy undertaken by a non-profit to generate revenue in support of its charitable mission".

In such a perspective, it is straightforward to name that first school the "earned income" school of thought. Within the latter however, we suggest a distinction between an earlier version, focusing on nonprofits, that we call the "commercial non-profit approach", on the one hand, and a broader version, embracing all forms of business initiatives, that may be named the "mission-driven business approach", on the other hand. This latter approach refers to the field of social purpose venture as encompassing all organizations that trade for a social purpose, including for-profit companies (Austin et al., 2006).

It should also be noted that some authors, such as Emerson and Twersky (1996), early provided an analysis shifting from a sole market orientation to a broader vision of business methods as a path towards achieving increased effectiveness (and not just a better funding) of social sector organizations. Even further, various activities undertaken by for-profit firms to assert their corporate social responsibility began to be considered, by some authors, as part of the whole range of initiatives forming the wide spectrum of social entrepreneurship (Boschee, 1995; Austin, 2000). Of course, this raises some fundamental conceptual issues such as the following: can any social value-generating activity be considered as an expression of social entrepreneurship, even if this activity remains marginal in the firm's overall strategy? 
To a large extent, the concept of social business as promoted by Muhammad Yunus (2010) can also be related to the "mission-driven business approach" although it also involves stronger conditions: "A social business is a non-loss, non-dividend company designed to address a social objective" (Yunus, 2010). This concept was mainly developed to describe a business model that focuses on the provision of goods or services to (very) poor customers, a new market segment (often called the "bottom of the pyramid") in the developing countries. The most often quoted case is the Grameen Danone joint company which provides, at very low prices, highly nutritive yoghurt to vulnerable populations in Bangladesh. Such a social business is supposed to cover all its costs through market resources. It is owned by (often large) investors who, at least in the Yunus' version, don't receive any dividend, profits being fully reinvested to support the social mission

\section{The "social innovation" school of thought}

The second school puts the emphasis on the profile and behaviour of social entrepreneurs in a Schumpeterian perspective as the one developed by the pioneering work of Young (1986). Along such lines, entrepreneurs in the non-profit sector are "change makers" as they carry out "new combinations" in at least one the following ways: new services, new quality of services, new methods of production, new production factors, new forms of organizations or new markets. Social entrepreneurship may therefore be a question of outcomes rather than just a question of incomes. Moreover, the systemic nature of innovation brought about and its impact at a broad societal level are often underlined.

Dees (1998:4) has proposed the best known definition of a social entrepreneur in that school of thought. He sees the latter as "playing the role of change agents in the social sector by adopting a mission to create and sustain social value, recognizing and relentlessly pursuing new opportunities to serve that mission, engaging in a process of continuous innovation, adaptation and learning, acting boldly without being limited by resources currently in hand, and finally exhibiting a heightened sense of accountability to the constituencies served and for the outcomes created". Today, such outstanding individuals are often portrayed as heroes of the modern times (Bornstein, 2004).

Although many initiatives of social entrepreneurs result in the setting up of non-profit organizations, many recent works of the social innovation school of thought tend to underline blurred frontiers and the existence of opportunities for entrepreneurial social innovation within the private for-profit sector and the public sphere as well.

Moreover, divergences between the "social innovation" school and the "earned income" school should not be overstated, though. Viewing social entrepreneurship as a missiondriven business is increasingly common among business schools and foundations which foster more broadly business methods, not just earned-income strategies, as a path towards social innovation. Various works stress a "double (or triple) bottom line" vision which can be adopted by all types of enterprise as well as the creation of a "blended value" in an effort to really balance and better integrate economic and social purposes and strategies (Emerson, 2006). 


\section{The EMES approach to social enterprise}

Although field initiatives blossomed up across Europe, with Italian social cooperatives as an inspiring model in the early 1990s, the concept of social enterprise as such did not really spread during those years. In the academic sphere, major analytical efforts were undertaken from the second part of the 1990s, especially by the EMES European Research Network $^{7}$, Indeed, as soon as 1996, i.e. before most of the European public policies were launched, a major research program funded by the European Commission was undertaken by a group of scholars coming from all EU member states. That group progressively has developed an approach to identify organizations likely to be called "social enterprises" in each of the fifteen countries forming the EU by that time.

The EMES approach derives from extensive dialogue among several disciplines (economics, sociology, political science and management) as well as among the various national traditions and sensitivities present in the European Union. Moreover, guided by a project that was both theoretical and empirical, it preferred from the outset the identification and clarification of indicators over a concise and elegant definition.

Such indicators were never intended to represent the set of conditions that an organization should meet to qualify as a social enterprise. Rather than constituting prescriptive criteria, they describe an "ideal-type" in Weber's terms, i.e. an abstract construction that enables researchers to position themselves within the "galaxy" of social enterprises. In other words, they constitute a tool, somewhat analogous to a compass, which helps analysts locate the position of the observed entities relative to one another and eventually identify subsets of social enterprises they want to study more deeply. Those indicators allow identifying brand new social enterprises, but they can also lead to designate as social enterprises older organizations being reshaped by new internal dynamics.

The indicators have so far been presented in two subsets: a list of four economic indicators and a list of five social indicators (Defourny 2001, 16-18). In a comparative perspective, however, it seems more appropriate to distinguish three subsets rather than two, which allows highlighting particular forms of governance specific to the EMES ideal type of social enterprise. In doing so, we will also recognize more easily many of the usual characteristics of social economy organizations which are refined here in order to highlight new entrepreneurial dynamics within the third sector (Borzaga and Defourny, 2001).

In such a slightly reshaped EMES approach, three criteria reflect the economic and entrepreneurial dimensions of social enterprises:

a) A continuous activity producing goods and/or selling services

Social enterprises, unlike some traditional non-profit organisations, do not normally have advocacy activities or the redistribution of financial flows (as, for example, many

\footnotetext{
${ }^{7}$ The letters EMES stand for "EMergence des Enterprises Sociales en Europe" - i.e. the title in French of the vast research project carried out from 1996 through 2000 by the network. The acronym EMES was subsequently retained when the network decided to become a formal international association. See www.emes.net
} 
foundations) as their major activity, but they are directly involved in the production of goods or the provision of services to people on a continuous basis. The productive activity thus represents the reason, or one of the main reasons, for the existence of social enterprises.

\section{b) A significant level of economic risk}

Those who establish a social enterprise assume totally or partly the risk inherent in the initiative. Unlike most public institutions, their financial viability depends on the efforts of their members and workers to secure adequate resources.

\section{c) A minimum amount of paid work}

As in the case of most traditional non-profit organisations, social enterprises may also combine monetary and non-monetary resources, voluntary and paid workers. However, the activity carried out in social enterprises requires a minimum level of paid workers.

Three indicators encapsulate the social dimensions of such enterprises:

\section{d) An explicit aim to benefit the community}

One of the principal aims of social enterprises is to serve the community or a specific group of people. In the same perspective, a feature of social enterprises is their desire to promote a sense of social responsibility at the local level.

e) An initiative launched by a group of citizens or civil society organizations Social enterprises are the result of collective dynamics involving people belonging to a community or to a group that shares a well-defined need or aim; this collective dimension must be maintained over time in one way or another, even though the importance of leadership (by an individual or a small group of leaders) must not be neglected.

\section{f) A limited profit distribution}

The primacy of the social aim is reflected in a constraint on the distribution of profits. However, social enterprises not only include organizations that are characterized by a total non-distribution constraint, but also organizations which - like co-operatives in many countries - may distribute profits, but only to a limited extent, thus allowing to avoid a profit-maximizing behaviour.

Finally, three indicators reflect the participatory governance of such enterprises:

\section{g) A high degree of autonomy}

Social enterprises are created by a group of people on the basis of an autonomous project and they are governed by these people. They may depend on public subsidies but they are not managed, be it directly or indirectly, by public authorities or other organisations (federations, private firms, etc.). They have both the right to take up their own position ("voice") and to terminate their activity ("exit").

\section{h) A decision-making power not based on capital ownership}

This criterion generally refers to the principle of "one member, one vote" or at least to a decision-making process in which voting power is not distributed according to capital shares on the governing body which has the ultimate decision-making rights. 
i) A participatory nature, which involves various parties affected by the activity

Representation and participation of users or customers, influence of various stakeholders on decision-making and a participative management often constitute important characteristics of social enterprises. In many cases, one of the aims of social enterprises is to further democracy at the local level through economic activity.

As already underlined, these indicators can be used to identify totally new social enterprises, but they can also lead to designate as social enterprises older organizations which have been reshaped by new internal dynamics. The EMES approach proved to be empirically fertile. This has been the conceptual basis for several EMES researches, in different industries as personal services or local development (Borzaga and Defourny, 2001) or work integration (Nyssens, 2006), sometimes enlarged to Central and Eastern Europe (Borzaga et al., 2008).

The first research carried out by the EMES Network also presented an initial attempt to outline a theory of social enterprise: an "ideal-typical" social enterprise could be seen as a "multiple-goal, multi-stakeholder and multiple-resource enterprise". These theorised features remained untested, though; they thus paved the way for further research. It is why EMES undertook another major research program to explore more deeply these hypotheses, through a comparative analysis of social enterprises in Europe. ${ }^{8}$ Although social enterprises are active in a wide variety of fields, including personal social services, urban regeneration, environmental services, and the provision of other public goods or services, researchers decided to focus on work integration social enterprises (WISEs), with a view to allowing meaningful international comparisons and statistical analysis. On such a basis, they made an inventory of the different existing types of social enterprise in the field of on-the-job training and work integration of low-qualified persons ${ }^{9}$.

\section{Social co-operatives as EMES-type social enterprises}

As stated earlier, social cooperatives represent one model of social enterprise: as all social enterprises, they are entrepreneurial initiatives driven by a social aim. As compared to other social enterprises, their main specificity lies in the fact they are embedded in the co-operative tradition of collective governance. However, they differ from traditional cooperatives because they seek to provide answers to needs of a whole community or some target groups in the community and not primarily to their own common needs.

It would be unfair not to identify some features of social co-operatives in the two USbased conceptions of social enterprise. A strong market orientation characterizing the earned income approach finds an important echo in the co-operative tradition which often defines itself as a more democratic way to organize an enterprise operating in the market as opposed to traditional non-profit and charitable organizations mostly relying on voluntary resources and public grants.

\footnotetext{
${ }^{8}$ Named PERSE, this project focused on the "Performance of Social Enterprises" in the field of work integration. Funded by the 5th Framework Program of the European Commission (DG Research), it was carried out in twelve EU countries from 2001 through 2004.

${ }^{9}$ Nyssens (2006).
} 
Although highlighting the role of an individual entrepreneur instead of a collective dynamics, the social innovation school of thought is certainly relevant for social cooperatives when the latter provide innovative answers to unmet social needs, which is often the case. Leading founders of social co-operatives may then be described as true social entrepreneurs as they act as key change makers. By the way, we are here touching an important issue which has often been under-estimated in the co-operative or social economy literature typically oriented toward economic democracy: in most types of economic undertakings, human energies need to be catalysed by a single or very few key leaders as many success stories of co-operatives show.

However, as we will show hereafter, the EMES approach of social enterprise is by far best suited to shed light on all specific features of social co-operatives in the whole world of social enterprise. Moreover, practically all following "world standards of social cooperatives" as adopted by the relevant section of the International Cooperative Alliance (CICOPA, 2011) are explicitly included in the EMES sets of indicators.

\section{1) An explicit general interest mission directly translated in the production of goods and services of general interest}

For the EMES approach, the production of goods and/or services does itself constitute the way in which the social mission is pursued. In other words, the nature of the economic activity is closely connected to the social mission: for instance, the production process involves low-qualified people if the goal is to create jobs for that target group ${ }^{10}$; if the social enterprise's mission is to develop social services, the economic activity is actually the delivery of such social services, and so on. This type of approach is also found in the social innovation school, which considers that social enterprises implement innovative strategies to tackle social needs through the provision of goods or services. Although the innovating behaviour may only refer to the production process or to the way goods or services are delivered, it always remains linked to the latter, the provision of such goods or services therefore representing the main reason for the existence of the social enterprise.

By contrast, for the "commercial non-profit approach", the trading activity is often simply considered as a source of income, and the nature of the traded goods or services does not really matter as such. So, in this perspective, social enterprises can develop business activities which are only related to the social mission through the financial resources they help to secure. More precisely, it is common for a US non-profit to establish a separate business entity under its control, to generate revenue from sales. Only this latter entity can then be labelled as a social enterprise according to this approach.

2) A non-state character and more generally a substantial independence from the public sector and from other entities, regardless of the forms and amounts of aid social cooperatives might receive.

\footnotetext{
${ }^{10}$ CICOPA states «work integration, which is a key mission of many social enterprises, should be considered as a service of genral interest to all intents and purposes, regardless of the types of goods or services they produce ».
} 
Social enterprises highlighted by EMES are generally created by a group of people and are governed by them in the framework of an autonomous project. This condition of autonomy clearly diverges from the conception of the "Social Enterprise Knowledge Network" (launched by Harvard University in Latin America), according to which a short-term project with a social value undertaken by a for-profit enterprise or a public body can be considered as a social enterprise (Austin et al., 2004: xxv).

\section{3) A governance structure potentially or effectively based on multi-stakeholder membership}

In contrast to the two other schools of thought, the ideal-typical social enterprise defined by EMES is based on a collective dynamics and the involvement of different stakeholders in the governance of the organization. The various categories of stakeholders may include beneficiaries, employees, volunteers, public authorities and donors, among others. They can be involved in the membership or in the board of the social enterprise, thereby creating a "multi-stakeholder ownership" (Bacchiega and Borzaga, 2003). Such a multistakeholder ownership is even recognized or required by national legislations in various countries (Italy, Portugal, Greece and France). ${ }^{11}$ Stakeholders can also participate through channels that are less formal than membership, such as representation and participation of users and workers in different committees in the everyday life of the enterprise. In many cases indeed, one of the aims of social cooperatives is to foster some forms of democracy at the local level through economic activity.

\section{4) A substantial representation of worker members}

Historically, CICOPA as well as CECOP, its European component, were formed to mainly represent workers' co-operatives and they later enlarged their membership to include some neighbouring categories such as social co-operatives where workers often are among key represented stakeholders. It is therefore not surprising that these umbrella organizations actually insist on the fact that worker-members should represent at least one third of votes in every governance structure of social co-operatives. In the case of work integration social co-operatives, at least $51 \%$ of the members should be workers and $51 \%$ of all workers (disadvantaged and other workers put together) should be members.

This is consistent with the way the EMES approach stresses participatory governance involving (without minimum thresholds) various parties affected by the activity. However, as shown by various EMES works (Nyssens, 2006; Davister et al., 2004), actual practices of WISEs do not always meet such strict requirements, even when under legal co-operative form. This is particularly true when social co-operatives are mainly devoted to provide employment to mentally disabled persons. This however does not

\footnotetext{
${ }^{11}$ In Italian social cooperatives, workers are members of the cooperative and disadvantaged workers should be members of the B-type cooperative that employs them, if this is compatible with their situation. The statutes may also require the presence of volunteers in the membership. In Portuguese "social solidarity cooperatives", users and workers must be effective members. In French "collective interest co-operative societies", at least three types of stakeholders must be represented: workers, users and at least a third category, defined according to the project carried out by the cooperative. As to Greek social co-operatives, they are based on a partnership between individuals of the "target group", psychiatric hospital workers and institutions from the community, and such different stakeholders have to be represented in the board of the organization.
} 
contradict the CICOPA's broader spirit of multi-stakeholder membership which has to reflect the primary social mission of the enterprise.

\section{5) Non-distribution or limited distribution of surplus}

There is here a full convergence of CICOPA and EMES as the latter considers the field of social enterprises includes organizations that are characterized by a total non-distribution constraint and organizations which may only distribute profits to a limited extent, thus avoiding a profit-maximizing behaviour. European legal frameworks, those embedded in the cooperative tradition as well as the more open models, also reduce the power of social enterprises' shareholders by prohibiting ${ }^{12}$ or limiting ${ }^{13}$ the distribution of profits. A convergence must be noted here with the US "commercial non-profit approach" (within the "earned income" school of thought) which explicitly locates social enterprise in the field of non-profit organisations, i.e. entities whose surplus is entirely retained by the organization for the fulfilment of its social mission. This is also in line with the way Yunus defines a social business as shareholders must accept not to receive any dividend. On the contrary, for the "mission-driven business approach" as well as for the "social innovation school of thought", social enterprises may adopt any kind of legal framework and may therefore distribute surplus to shareholders. It is possible here to argue such a profit distribution in some cases might put into question the primacy of social objectives: in very broad conceptions of social enterprise, the latter may include an increasing number of firms which claim to look at a double or triple bottom line (Savitz, 2006) but actual practices may reveal the economic line clearly dominate the other (social and environmental) dimensions.

\section{6) One member - one vote or limitation to the rights of shareholders}

Although not explicitly repeated by CICOPA, the co-operative tradition of course requires the application of the rule "one member- one vote". While the other social enterprise schools of thought do not say anything about distribution of voting power, the EMES approach once more appears closer to social co-operatives by stressing the decision-making power is not based on capital ownership. For the research network, this means at least that voting rights in the governing body that has the ultimate decisionmaking power is not distributed according to capital shares. Such rules are reflected in most legal frameworks designed for social enterprises and those of explicit co-operative form generally require the strict application of the rule "one member, one vote". ${ }^{14}$

\footnotetext{
12 In Portuguese "social solidarity co-operatives" and Spanish "social initiative cooperatives", any distribution of profit is forbidden.

${ }^{13}$ Distribution of profit is limited by strong rules in Italian "social cooperatives" and Belgian "social purpose companies". The British "community interest company" includes an asset lock which restricts the distribution of profits and assets to its members; the dividend payable on the shares is subject to a cap set by the regulator.

${ }^{14}$ It is the case for the Italian "social cooperative", the Portuguese "social solidarity co-operative", the Spanish "social initiative cooperative" and the French "collective interest co-operative society". In the Belgian "social purpose company", no single person can have more than $1 / 10^{\text {th }}$ of the total number of votes linked to the shares being represented.
} 


\section{Conditions of emergence and development of social co-operatives}

Being a type of organization mixing characteristics of co-operatives at large and general interest non-profit organizations, social co-operatives can be analysed, at least partly, through the lenses of both the co-operative literature as well as the non-profit literature. More particularly, theories explaining the "raisons d'être" of NPOs can be applied to them as already shown by various authors. Hansmann (1996) is probably the author who provided the most integrated analysis of both co-operatives and non-profits in a new institutional economics perspective. Gui (1991), Ben-Ner (1995), Bacchiega and Borzaga (2001) are among those who tried to cross-fertilize theories of both types of organizations.

Here we just would like to propose a complementary socio-economic perspective on the conditions under which social co-operatives emerged and might continue to develop. Our analysis is rooted in an inductive approach adopted in two major international comparative research projects which focused on the profile, the size and the components of the "social economy" defined as a third sector embracing all types of not-for-profit organizations such as co-operatives, mutuals and associations, three components rather easy to identify in many Western countries (Defourny, Monzon Campos, 1992; Defourny, Favreau, Laville, 1998). More particularly, comparisons among countries both in Europe and North America as to historical contexts in which social economy organisations emerged in the $\mathrm{XIX}^{\text {th }}$ and early $\mathrm{XX}^{\text {th }}$ centuries made clear that at least two conditions were met at the same time for most important waves of such organizations (Defourny and Develtere, 1999). This was particularly obvious for co-operative movements (Defourny, 1995). We suggest here that such those two conditions can also help understanding the new wave of social co-operatives as well as its prospects of development.

\section{A. The co-operative yesterday, a child of "necessity and collective identity"}

This expression, "la coopération est fille de la nécessité" was often underlined by Henri Desroche (1976), a French sociologist. Indeed, history teaches us co-operatives are born of pressures resulting from significant unsatisfied needs and that they address acute problems. Put succinctly, they respond to a "condition of necessity": consumer cooperatives were the result of collective efforts by people of meagre means seeking to purchase their food at a lower price. As for producers' co-operatives, they often represented a reaction by skilled artisans who sought to preserve their trades and remain masters of their work, instead of becoming locked into wage-earning, which in no way provided the social benefits we know today. In addition, we should not overlook those who were simply thrown out of work by changes in capitalism and sometimes attempted to deal with their predicament by creating their own joint businesses under cooperative forms.

History of the social economy also teaches us that it is driven by a second force, one that is as powerful and as vital as the first: membership in a social group unified by a collective identity. For example, during the XIXth century and the first half of the XXth 
century, the social economy dynamics reflected a class culture that was, to be sure, dominated, but which showed considerable solidarity.

In industrial areas, the bonds that united members of co-operatives, mutual aid societies and other worker associations were their living and working conditions, their folk cultures and the struggles that allowed them to experience what Touraine has called "the unifying power of conflict". This concept helps to explain why movements that saw themselves as levers of societal transformation supported the social economy.

A parallel analysis of the rural social economy (agricultural co-operatives and mutual aid societies, rural credit unions, peasant associations, etc.) produces similar results. In many instances, the tenacity of the more traditional social and cultural forces (driven by religion, family values and village identity) provided sufficient social cohesion for collective projects of the co-operative type to emerge in the countryside. But certain extraordinary success stories reveal even more clearly the importance of collective identity as an underlying factor in the rise of co-operatives. For example, about one hundred years ago, the Desjardins co-operative movement in Quebec created numerous rural credit unions that still form the principal banking network in this region. It is impossible to understand such a huge development without understanding the will of an entire people to defend its French-speaking, Catholic and mainly rural identity in the face of the Anglo-Saxon Protestant and mainly urban domination that prevailed throughout North America. In Belgium, the story of the Flemish agricultural co-operatives, which are still very powerful today, may be understood in a similar way: the small farmers, who spoke only Flemish, sought to improve their living conditions and simultaneously assert their identity in an environment dominated by a French-speaking and urban bourgeoisie and nobility. As a final and more contemporary example, there is no doubt that the affirmation of Basque identity in the face of Castilian hegemony constituted a fundamental driving force in the birth and growth of the Mondragón co-operative complex, even though the tremendous need for post-war reconstruction was also a contributing factor.

\section{B. Social cooperatives today: answering pressing social demands on the basis of a "shared destiny"}

In industrialized countries, most pressing needs which gave an impulse to co-operatives are now met by the latter or by other firms. Obviously however, the "condition of necessity" still exists in most countries. In particular, because of the decline of the welfare state and the unemployment crisis, many people who were previously protected now have new needs that have to be met. Generally speaking, new social demands are now being made, demands which the market and public intervention cannot meet, or can no longer meet adequately.

Demands include those for professional requalification and reintegration of people who have been marginalised on the labour market; economic rehabilitation of disadvantaged urban neighbourhoods, and even revitalisation of deserted rural areas. The list of 
contemporary challenges can be extended further: the growing number of "new poor" and homeless, juvenile delinquency, the isolation of the elderly, the inadequacy of early childhood facilities, the failure of the educational system for a growing part of the youth, the destruction of the environment, and so forth.

In more analytical terms, these social demands concern, most of the time, the provision of quasi-collective goods. Quasi-collective goods differ from classical collective goods in the sense that they are private goods, characterized by exclusion and rivalry in their consumption, whose consumption produces collective benefits for the community. For example, childcare improves the functioning of the labor market, and some domiciliary services to elderly people generate externalities in terms of public health. Many community services also contribute to strengthening social cohesion by reducing the isolation of the elderly, socializing and educating children of vulnerable families, fostering links between neighbors. The supply of these services which attract families and firms to locate in neighbourhood and the development of work integration social enterprise which integrate unemployed people contribute to local development.

These collective benefits can be considered as multilateral externalities that have the properties of a collective good. Not only, these goods are source of collective benefits, but they also are trust goods due to their "relational" dimension as the kind of relationship that arises between the provider and the user, who can be vulnerable, determines the quality of the service. They are experience goods since their quality can only be known ex post. Information is, therefore, not only asymmetric but, fundamentally, incomplete. Trust between stakeholders therefore plays a crucial role in this area.

It is well-known that collective externalities and imperfect information are sources of market failures. We do argue hereafter that social cooperatives are driven, today, by a sense of "shared destiny" which can be a channel to overcome some of these limits.

As a matter of fact, strong collective identities are now more difficult to observe than in the past in industrialized countries. Indeed, there are numerous factors that militate against it, including pervasive individualism, increasing marginalization of disadvantaged people, a weakening of traditional social bonds associated with religion, trade unionism, and moral standards. Indeed, most contemporary co-operatives are no longer a vehicle for entrenched collective identities. However, in addition to driving forces made of members' mutual interest, part of new co-operative initiatives are still rooted in various forms of "collective awareness", such as the widespread awareness of the need to promote social justice, protect the environment, promote social and professional integration of disadvantaged individuals, and develop new relationships with the nations of the southern hemisphere. Even more, we would argue that many groups who are launching social co-operatives or more widely social enterprises, are driven by a sense of a "shared destiny", quite different from traditional collective identities but nevertheless profound. What they share is a common awareness leading them to take up challenges such as those just listed. 
Such a sense of shared destiny particularly leads to actual social entrepreneurship when it is felt that neither the state nor conventional market forces will provide satisfactory responses. The aim to benefit the community may be seen as explicitly enhancing collective benefits. Here, collective benefits are not simply induced by economic activity (side effects) but are, rather, a dimension claimed by those who promote and actually undertake the activity (Laville, Nyssens, 2001). The pursuit of collective benefits constitutes the main incentive and explains the commitment of the stakeholders who create the social cooperative. While positive externalities discourage private investment in a for-profit firm by socializing the benefits (Callon, 1999), positive externalities are among the very reasons why stakeholders being conscious of their shared destiny join a collective action to create economic activities through social enterprises.

The development of multiple stakeholders' enterprise provides a way of to organize appropriate recognition of these collective benefits. By involving different stakeholders in the governance structure, social cooperatives reveal and collectively build the actual collective aspect of these benefits thanks to the various sensibilities of the stakeholders. Social cooperatives are collective entities based on an interactive process among different types of stakeholders, through formal channels but also informal ones without these formally participating in the board of the enterprise. This can be connected to the importance of the representation of demand side stakeholders within the organizations in order to create trust (Ben-Ner and Van Hoomissen, 1991). Trust is not only created by exhibiting a formal legal structure limiting or prohibiting distribution of profit but also by involving stakeholders in the construction of the organisation. This "co-construction" dynamic (Laville, 2010) can help to overcome imperfect information and opportunistic behaviours between user and provider, donor and provider or employer and employee.

\section{The role of public policies}

It is well-know the presence of collective benefits renders market-based financing insufficient. As a matter of fact, the viability of most social enterprises depend on the long-term capacity of their leaders to combine different kind of resources and these combinations will vary heavily according to the field and the assigned social mission. This generally means selling goods or services to the possible extent as well as mobilising donations, and volunteering and /or applying for public funding to compensate the organization for services provided for free or below the cost of production (Gardin, 2006).

While the role of social enterprises in clearing up emerging social demands and in introducing innovative practices often supported by philanthropic resource is increasingly acknowledged, governments may sometimes consider the leadership of the scaling up phase is their responsibility. This may take place when public authorities backed by the public opinion are particularly concerned with limitations of traditional philanthropy and venture philanthropy: as listed by Salamon (1987), a "philanthropic shortfall" (not enough resources), a "philanthropic particularism" (trend to support specific groups or causes) and a "philanthropic paternalism" (certain individuals are in a position to determine which services will be provided since they control the source of funding). 
In the European context indeed, the process of institutionalization of social enterprise has often been closely linked to the evolution of public policies (Defourny, Nyssens, 2011). Social enterprises are not just residual actors filling gaps of the market or the State. In fact, social enterprises significantly influence their institutional environment and they contribute to shaping institutions including public policies. The sustainability and future growth of social enterprises can be, therefore, linked to recognition by government funding sources that social enterprises make a distinctive contribution to the community.

For example, social enterprises among which various types of social co-operatives were pioneers in promoting the integration of excluded persons through a productive activity. A historical perspective shows that they have contributed to the development of new public schemes and legal frameworks, which in turn became channels for social innovation. The conditions imposed to social enterprises by the different European legal frameworks can be seen as signals often first created by social enterprises themselves and furthermore as guarantees that allow governments to provide financial support to social enterprises. Without such guarantees (often involving a strict non-distribution constraint), the risk would be greater that public subsidies just induce more profits to be distributed among owners or managers. Participatory governance structures which are found in all types of social co-operatives as well as in some other social enterprises may also be seen as another built-in guarantee of the social aim's primacy. In turn, such public support often allows social enterprises to avoid purely market-oriented strategies, which, in many cases, would lead them away from those who cannot afford market prices and nevertheless constitute the group that they target in accordance with their social mission. Public policies are also supposed to avoid that the neediest groups depend primarily on private philanthropy.

\section{Conclusions}

The historical perspective we have adopted suggests that the distinctive conceptions of social enterprise and social entrepreneurship are deeply rooted in the social, economic, political and cultural contexts in which these organizations emerge. We have underlined the specific place of the social co-operative embedded in the European co-operative tradition, in the whole world of social enterprise. Social co-operatives are characterized by collective governance and compared to traditional co-operatives, they seek to provide answers to needs of a whole community or some target groups in the community and not primarily to their members' common needs.

Specific governance structures of the social co-operatives are put forward with a twofold objective. First, a democratic control and/or a participatory involvement of stakeholders reflect the quest for more economic democracy as in the whole co-operative tradition. This can also be seen as an efficient channel to collectively build a capital of trust as well as the social mission in the field of quasi-collective goods. Social co-operatives therefore add built-in collective mechanisms to constraints on the distribution of profits with a view to protecting and strengthening the primacy of the social mission which is at the very heart of the organization. Secondly, those two combined guarantees (often involving a strict non-distribution constraint) often act as a "signal" allowing public authorities to 
support social enterprises in various ways (legal frameworks, public subsidies, fiscal exemptions, etc.) in order to foster production of collective benefits.

Creating original operational models which mix various kinds of resources, combining various categories of stakeholders and pursuing social aims as well as economic viability, social co-operatives probably have considerable prospects of development like the whole spectrum of social enterprises among which they represent a model particularly driven by a collective dynamic and a quest of economic democracy. These features find explicitly echoes in the way the EMES Network defined its ideal-type social enterprise and analysed social enterprises in the last fifteen years: through an economic and entrepreneurial behaviour, a primary social aim and a participatory governance structure.

\section{References}

Austin, J. E. (2000), The Collaboration Challenge: How Nonprofits and Businesses Succeed through Strategic Alliances, San Francisco: Jossey-Bass.

Austin, J.E, Leonard B., Reficco E., Wei-Skillern J., (2006), Social Entrepreneurship: It's for Corporations too, in: Nicholls, A. (ed.) Social Enterpreneurship, New Models of Sustainable Social Change, Oxford University Press, 169-180.

Bacchiega, A. and Borzaga, C. (2001), Social Enterprises as Incentive Structures: an Economic Analysis", in Borzaga, C. and Defourny, J. (eds) The Emergence of Social Enterprise, London and New York: Routledge, 273-94.

Bachiegga, A. \& Borzaga C. (2003), "The Economics of the Third Sector" in H.K. Anheier \& A. Ben-Ner (eds), The Study of the Nonprofit Enterprise, Theories and Approaches, New York: Kluwer Academic/Plenum Publishers.

Ben-Ner, A. and Van Hoomissen, T. (1991), Nonprofit Organizations in the Mixed Economy: A Demand and Supply Analysis", Annals of Public and Cooperative Economics, vol. 62, 519-550.

Ben-Ner, A. (1987), Producer Cooperatives: Why Do they Exist in Capitalist Economies?, in W.W. Powell, The Nonprofit Sector: a Research Handbook, Yale University Press, 434-449.

Bornstein D. (2004), How to Change the World: Social Entrepreneurs and the Power of NewIdeas, New York: Oxford University Press.

Borzaga, C., (2004), The Third Sector in Italy, in A. Evers \& J.-L. Laville (eds), The Third Sector in Europe, Cheltenham, UK, Northampton, MA: Edward Elgar.

Borzaga, C. \& Defourny, J. (eds) (2001) The Emergence of Social Enterprise, London and New York: Routledge (paperback edition: 2004).

Borzaga, C., Galera, G, \& Nogales, R. (eds.) (2008), Social Enterprise. A New Model for Poverty Reduction and Employment Generation, United Nations Development Programme, Bratislava Regional Centre.

Boschee, J. (1995), "Social Entrepreneurship", Across the Board, March, 20-25. 
Callon M., (1999). La sociologie peut-elle enrichir l'analyse économique des externalités? Essai sur la notion de cadrage-débordement, dans D. Foray \& J. Mairesse, (eds), Innovation et performance: Approches interdisciplinaires, Editions EHESS, Paris.

CICOPA (2011), World Standards of Social Cooperatives, International Organization of Industrial, Artisanal and Service Producers' Cooperatives, Brussels.

Davister, C., Defourny, J. and Grégoire, O. (2004), Les entreprises sociales d'insertion dans l'Union Européenne : un aperçu général, Revue des Etudes Coopératives, Mutualistes et Associatives (RECMA), no 293, 24-50. (English version: EMES Working Papers Series, $\mathrm{n}^{\circ}$ 04/04.)

Dees, J. G. (1998), The Meaning of Social Entrepreneurship, Working Paper, Kauffman Center for Entrepreneurial Leadership.

Dees, J. G. \& Anderson B.B. (2006), Framing a Theory of Social Entrepreneurship: Building on Two Schools of Practice and Thought, in Research on Social Enterpreneurship ARNOVA Occasional Paper Series, vol.1, no 3, 39-66.

Defourny, J. (2001), From Third Sector to Social Enterprise , in C. Borzaga \& J. Defourny (eds) The Emergence of Social Enterprise, London and New York: Routledge, $1-28$.

Defourny, J. (1995), L'avenir des pratiques coopératives dans un monde en mutation, in M. Th. Seguin (ed.), Pratiques coopératives et mutations sociales, L'Harmattan, Paris, 13-28.

Defourny, J. \& Develtere, P. (2009), The Social Economy: The Worldwide Making of a Third Sector, in : J. Defourny, P. Develtere, B. Fonteneau \& M. Nyssens, The Worldwide Making of the Social Economy, The Hague and Leuven : Acco, 15-40.

Defourny, J., Favreau, L. \& Laville, J.-L., eds. (1998), Insertion et nouvelle économie sociale, un bilan international, Paris : Desclée de Brouwer.

Defourny, J. \& Kim, S.-Y. (2011), "Emerging Models of Social Enterprise in Eastern Asia : A Cross-Country Analysis", in J. Defourny \& Y.Y. Kuan, eds., Social Enterprise in Eastern Asia, Social Enterprise Journal, special issue, Vol. 7, No 1, 86-101.

Defourny J. \& Monzón Campos J.-L., eds., (1992), Economie sociale - The Third Sector, De Boeck, Brussels and Paris.

Defourny J. \& Nyssens M., (2008), Social Enterprise in Europe: Recent Trends and Developments, Social Enterprise Journal, vol. 4, no 3, 202-228.

Defourny, J. \& Nyssens, M. (2010), Conceptions of Social Enterprise and Social Entrepreneurship in Europe and the United States: Convergences and Divergences, Journal of Social Entrepreneurship, Vol., 1, No 1, 32-53.

Desroche, H., (1976), Le projet coopératif, Les Editions Ouvrières, Paris.

Drayton, W. \& MacDonald, S. (1993), Leading Public Entrepreneurs, Arlington: Ashoka: Innovators for the Public.

Emerson, J. \& Twersky, F. (1996), New Social Entrepreneurs: The Success, Challenge and Lessons of Non-profit Enterprise Creation, San Francisco: Roberts Foundation. 
Emerson, J. (2006), "Moving Ahead Together: Implications of a Blended Value Framework for the Future of Social Entrepreneurship", Nicholls, A. (ed.) (2006) Social Enterpreneurship, New Models of Sustainable Social Change, Oxford University Press, 391-406.

Esping-Andersen, G. (1999), Social Foundation of Postindustrial Economies, New York: Oxford University Press.

Evers, A. and Laville, J.-L. (eds) (2004) The Third Sector in Europe, Cheltenham: Edward Elgar

Favreau, L (1998), Le développement économique communautaire in J. Defourny, L. Favreau \& J.-L. Laville, eds. , Insertion et nouvelle économie sociale, un bilan international, Paris : Desclée de Brouwer.

Galera, G. \& Borzaga, C., (2009), Social Enterprise : an International Overview of its Conceptual Evolution and Legal Implementation, Social Enterprise Journal, Vol. 5, No $3,210-228$.

Gardin, L. (2006), A Variety of Resource Mixes inside Social Enterprises, in M. Nyssens (ed.), Social Enterprise - At the crossroads of market, public policies and civil society, London and New York: Routledge, 111-136.

Gui, B. (1991), The Economic Rationale for the Third Sector, Annals of Public and Cooperative Economics, Vol. 62, No 4, 551-572.

Hansmann, H. (1996), The Ownership of Enterprise, Cambridge: Harvard University Press.

Hicks, A. \& Kenworthy, K. (2003), Varieties of Welfare Capitalism, Socio-Economic Review, 1: 27-61.

Hulgård, L. (2004), Work Integration Social Enterprises in Denmark, EMES Working Papers, No 04/08.

Kerlin, J. (2006), Social Enterprise in the United States and Europe: Understanding and Learning from the Differences, Voluntas, Vol. 17, No 3, 247-263.

Laville, J.L. (2010), Solidarity Economy. in : Hart K., Laville J.L., Cattani C., The Human Economy, a Citizen's Guide, London : Polity Press, 225-235.

Laville, J.-L. \& Nyssens, M. (2001), The Social Enterprise. Towards a Theoretical Socioeconomic Approach, in Borzaga, C. \& Defourny, J. (eds) The Emergence of Social Enterprise, London, New York: Routledge, 312-332.

Lewis, J., (1999), Reviewing the Relationships Between the Voluntary Sector and the State in Britain in the 1990's, Voluntas, Vol. 10, No 3, 255-270.

Mendell, M. (2010), Reflections on the evolving landscape of social enterprise in North America, Policy \& Society, 243-256

Nicholls, A. (ed.) (2006) Social Enterpreneurship, New Models of Sustainable Social Change, Oxford University Press.

Nyssens, M. (ed.), (2006) Social Enterprise - At the Crossroads of Market, Public Policies and Civil Society, London and New York: Routledge. 
Nyssens M. (2009), Social Enterprises in Western Europe, in J. Kerlin (ed.), Social Enterprise: a Global Perspective, Lebanon: University Press of New England, 12-34.

Salamon (1987), Partners in Public Service: The Scope and Theory of GovernmentNonprofit Relations, In: W. W. Powel. The Nonprofit Sector. A Research Handbook. Yale University Press, 99-117.

Salamon, L.M., Sokolowski, S.W. and associates, (2004) Global Civil Society; Dimensions of the Nonprofit Sector, volume 2, Kumarian Press

Skloot E. (1987), "Enterprise and Commerce in Non-profit Organizations" in W.W. Powell (ed.), The Non-profit Sector: a Research Handbook, New Haven, CT: Yale University Press.

Stryjan, Y. (2004), "Work Integration Social Enterprises in Sweden." EMES Working Papers, No 04/02.

Young, D. (1983), If Not for Profit, for What?, Lexington, Mass.: Lexington Books.

Young, D. (1986), Entrepreneurship and the Behavior of Non-profit Organizations: Elements of a Theory, in S. Rose-Ackerman (ed.), The Economics of Non-profit Institutions, New York: Oxford University Press, 161-184.

Young, D. \& Salamon, L.M. (2002), Commercialization, Social Ventures, and For-Profit Competition, in Salamon, L.M. (ed.) The State of Nonprofit America, Washington DC: Brookings Institution, 423-446.

Yunus, M. (2010), Building Social Business. Capitalism that can serve humanity's most pressing needs, Public Affairs. 